\title{
ФУНКЦИОНИРОВАНИЕ СИСТЕМЫ ОБЕСПЕЧЕНИЯ ВНУТРЕННЕЙ БЕЗОПАСНОСТИ В ГОСУДАРСТВЕННОМ МЕХАНИЗМЕ США
}

Л юбое государство (как политическая организация общества, которая распространяет свою власть на все население в пределах территории страны, издает юридически обязательные веления, обладает суверенитетом, а также специальным аппаратом управления и принуждения) ${ }^{1}$ для эфрфективного решения возникающих перед ним задач обладает специальным механизмом.

В соответствии с решаемыми задачами (защита национальных интересов от внешних или внутренних угроз) система обеспечения национальной безопасности (СОНБ) имеет сложную структуру, представляющую из себя совокупность двух тесно взаимосвязанных систем более низкого уровня, обеспечивающих защиту жизненно важных интересов личности, общества и государства от угроз извне и внутри страны.

Важной особенностью функционирования СОНБ государства является присутствие нескольких одинаковых элементов (они универсальны практически для любой страны - это вооруженные силы, органы разведки, контрразведки, полиции) и их одновременная деятельность в рамках организационных структур как системы обеспечения внешней безопасности государства, так и

\footnotetext{
${ }^{1}$ См.: Марченко М.Н., Байтин М.И., Керимов Д.А., Крылов Б.С., Мамут Л.С. Общая теория государства и права. Академический курс. 3-е изд. - М., 2007. Т. 1. - С. 120; Хропанюк В.Н. Теория государства и права. - М., 1993. - С. 47.
}

системы обеспечения внутренней безопасности государства ${ }^{2}$.

Значение этих элементов в каждой стране различно, но для всех современных государств характерна ведущая роль вооруженных сил и органов разведки в системе обеспечения внешней безопасности государства и вспомогательная, хотя и очень важная, в системе обеспечения внутренней безопасности страны. Органы полиции, наоборот, в системе обеспечения внутренней безопасности государства занимают ведущее положение, а в системе обеспечения внешней безопасности - вспомогательное ${ }^{3}$.

Ядро СОВБ США, его основу, составляет полицейская система Соединённых Штатов. Она функционирует в системе исполнительных органов власти, которая наряду с органами законодательной и судебной власти и образует СОВБ

\footnotetext{
2 В настоящей статье под термином «полиция» мы, как уже упоминалось, в соответствии с принятыми в 2002 г. Генеральной ассамблеей Интерпола «Всеобщими стандартами борьбы с коррупцией в полицейских органах и ведомствах», имеем ввиду все государственные и муниципальные органы, на которые возложена ответственность за охрану правопорядка в пределах государственных границ конкретной страны, вне зависимости от особенностей их наименования в отдельных государствах.

3 См.: Быков А.В. Система обеспечения внутренней безопасности государства. - М., 2007. - С. 9.
} 
страны. Таким образом, организационная структура СОВБ США состоит из трех подсистем, каждая из которых является самостоятельной системой более низкого уровня, реализующей функции по обеспечению безопасности государства от внутренних угроз в соответствии с конституционным принципом разделения единой государственной власти на три относительно независимые ветви: законодательную, исполнительную и судебную.

В отличие от полиции, жандармерии и пенитенциарных органов (именно эти государственные правоохранительные институты составляют ядро полицейской системы любого современного государства), вооруженные силы страны и органы государственной безопасности (разведка и контрразведка в зависимости от структуры органов исполнительной власти конкретного государства могут организационно входить в оба вышеперечисленных элемента полицейской системы), являясь важной частью СОВБ страны и полицейской системы как её составной части, всё же большую часть своей деятельности по обеспечению национальной безопасности государства осуществляют в рамках системы обеспечения внешней безопасности страны. Их главная цель деятельности (особенно вооруженных сил) - защита суверенитета государства и его безопасности от внешних угроз ${ }^{4}$.

Вооруженные силы демократического государства в его повседневной жизни в охране правопорядка практически не используются (исключением из этого правила являются страны, имеющие в структуре своих СОВБ жандармерию Франция, Италия, Испания, Португалия и др.). Но при осложнении оперативной обстановки в сфере охраны правопорядка внутри государства картина резко меняется. В кризисных ситуациях любое самое демократическое государство (не говоря уже о тоталитарных) немедленно использует вооруженные силы для нормализации обстановки в стране, но только делает это строго в рамках подробнейшим образом регламентированного законодательства, исключающего узурпацию власти со стороны военных.

Характерной особенностью американской системы обеспечения внутренней безопасности государства, является традиционное использование частей и соединений вооруженных сил (главным образом Национальной гвардии, а также сухопутных войск и морской пехоты) для подавления «гражданских беспорядков» (ст. 4, раздел

${ }^{4}$ См.: Быков А.В. Указ. соч.
4 Конституции США гарантирует каждому штату федеральную помощь от внутреннего и внешнего насилия $)^{5}$.

Специфической особенностью функционирования СОВБ США является также конституционное право граждан Соединённых Штатов хранить и носить оружие. Это право обеспечивает 2 поправка Конституции США, принятая в 1791 г., которая гласит: «Поскольку хорошо организованная милиция необходима для безопасности свободного государства, право народа хранить и носить оружие не должно нарушаться» ${ }^{6}$. Это конституционное право американцев достаточно подробно регламентируется федеральным законодательством и законодательством штатов.

И дело здесь не только в сверхмощном оружейном лобби в Конгрессе, хотя оно имеет огромное значение (ведь торговля оружием приносит миллиардные прибыли), а в особенностях возникновения, становления и развития американской государственности и, как следствие, особенностях национального менталитета.

Ведь государство в США (как и полиция) создавалось снизу, в условиях непрерывной борьбы поселенцев с индейцами и колониальным игом Англии. Все свободное население было поголовно вооружено и отцы-основатели США не могли не учитывать этот фракт при написании конституции. В настоящее время столь огромное количество огнестрельного оружия на руках у граждан страны не только приводит с незавидной регулярностью к серьезнейшим ЧП, но и, как это ни парадоксально, является сдерживающим преступность фактором.

Американская модель СОВБ состоит из 2 уровней: федерального и субъектов фредерации - штатов (полицейские органы муниципальных образований являются самыми многочисленными среди элементов полицейской системы любого штата). Это две самостоятельные, но очень тесно взаимодействующие между собой (особенно эфрфективно и четко это организовано после 11 сентября 2001 г.) подсистемы единой системы обеспечения внутренней безопасности страны.

Важной особенностью деятельности полицейских сил этого уровня в США является то, что полиция штатов, графств (округов) и городов не представляет собой жесткой замкнутой иерархической системы. Все полицейские департаменты, входя-

\footnotetext{
5 Конституция США. - М., 1993. - С. 17.

${ }^{6}$ Конституция США. - М., 1993. - С. 20.
} 
щие в него, в своей повседневной жизни руководствуются действующим федеральным законодательством и законами штатов. Они организационно независимы как друг от друга, так и от федеральных полицейских органов (лишь координируют между собой свою деятельность). Их основной обязанностью является обеспечение исполнения как федеральных, так и региональных правовых норм, причем все решения по вопросам организации и деятельности конкретного полицейского департамента с учетом законодательных особенностей и сложившихся традиций принимаются на каждом уровне.

При этом, служебные полномочия конкретного полицейского служащего ограничиваются районами юрисдикции его полицейского агентства границами конкретного муниципалитета. В настоящее время в различных субъектах фредерации Соединённых Штатов Америки насчитывается всего около 18000 полицейских агентств,7 из них около 1700 крайне малочисленны - они имеют в своем составе не более 30 сотрудников полиции (осрицеров - по американской терминологии) ${ }^{7}$.

Основными задачами полицейских органов штатов являются: патрулирование автомобильных дорог на всей территории штата; осуществление обычных полицейских функций на территории, где отсутствуют муниципальные полицейские органы; помощь муниципальным полицейским органам в проведении уголовных расследований по их просьбе; регистрация автотранспорта, проведение его техосмотров и выдача водительских удостоверений; подготовка личного состава для полиции штата и муниципальных полицейских агентств по их просьбе; информационное обеспечение всех полицейских структур на территории штата, ведение всей справочной и архивной документации.

Основу полицейских сил базового уровня полицейской системы США и самую многочисленную ее часть - более 700000 человек, составляют полицейские агентства (департаменты) муниципалитетов, графств и иных специализированных полицейских организаций (полиция национальных парков, портов, университетских городков и т.д.).

Таким образом, американские специалисты сознательно идут на максимальную децентрализацию полицейских сил на местном и региональном уровнях, чтобы использовать все преимущества децентрализации функций управления полицией. С их точки зрения ставится заслон на пути к всевластию государства, избранная система является

\footnotetext{
7 См.: Шалягин Д.Д. Полиция США. - М., 2001. - С. 5.
}

средством защиты интересов граждан. Учитывается то, что рядовые граждане страны предпочитают иметь дело с выборными лицами, а не безликими государственными учреждениями.

В настоящее время региональные полицейские организации в Соединенных Штатах постоянно и интенсивно ищут способы оптимального взаимодействия, не ущемляющего их самостоятельности. Весьма полезным с этой точки зрения признается, в частности, заключение двухсторонних и многосторонних договоров о сотрудничестве и регулярное проведение целевых конференций по линиям работы. Необходимо также учитывать тот фракт, что достаточно многочисленные федеральные полицейские силы (в них проходят службу более 50 000 человек), входящие в основной уровень СОВБ страны, успешно дополняют в повседневной жизни деятельность полицейских агентств базового уровня, что в итоге позволяет говорить о непрерывной и достаточно жесткой конкуренции между полицейскими органами двух подсистем в рамках единой системы. Следствием этой конкуренции является повышение эффрективности деятельности полицейской системы США в частности и СОВБ Соединенных Штатов в целом, что не осталось без внимания российских специалистов ${ }^{8}$.

Одно из важнейших мест в системе обеспечения внутренней безопасности Соединенных Штатов занимает Министерство обороны. Законодательство США прямо предусматривает в мирное время, в случае необходимости, применение армейских частей и соединений для урегулирования внутригосударственных конфрликтов. Все военнослужащие вооруженных сил США, принимая присягу, обязуются защищать Конституцию страны, как от внутренних, так и от внешних врагов. По мнению американских специалистов, наиболее подходящей для решения подобных весьма специфических задач армейской структурой является организованный резерв вооруженных сил страны - Национальная гвардия США.

Ее формирования являются важнейшим компонентом как вооруженных сил, так и полицейской системы США. Вот как о её значении в обеспечении внутренней безопасности страны отзывался бывший министр юстиции США Рамсей Кларк: «Если мы хотим, чтобы у нас продолжала существовать наша фредеративная система, именно Национальной Гвардии предстоит подавлять вну-

\footnotetext{
${ }^{8}$ См.: Крылов Б.С. Полиция США. - М., 1972. - С. 5; Губа-
} нов А.В. Полиция Запада. - М., 1993. - С. 37. 


\section{Полицейская деятельность 1 • 2013}

тренние беспорядки, не дожидаясь, пока будут вызваны федеральные войска» ${ }^{9}$.

Таким образом, в мирное время все формирования Национальной гвардии (сухопутные войска и ВBC) являются частями вооруженных сил штатов, на территории которых они дислоцируются. Все части и соединения Национальной гвардии по месту дислокации находятся в прямом подчинении губернаторов штатов и немедленно используются ими при необходимости, как для поддержания общественного порядка, так и для ликвидации последствий стихийных бедствий и решения других задач (например, для прикрытия границы с Мексикой от проникновения наркотиков).

В случаях, когда органы государственной власти штатов не могут самостоятельно справиться с возникшими чрезвычайными обстоятельствами, парламент или губернатор штата (на основании ст. 4 разд. 4 Конституции США) вправе запросить фредеральную помощь, а Президент США обязан ее предоставить ${ }^{10} .10$ Кроме того, Президент США име- ет право вмешаться и самостоятельно, если по его мнению обстановка в конкретном штате угрожает национальной безопасности всей страны.

В любом современном государстве устойчивой, стабильно и эффективно работающей может быть лишь та социальная система, которая фрункционирует на основе демократических процедур, и система обеспечения национальной безопасности (СОНБ) любого государства не является исключением из этого правила. Американские руководители это поняли первыми в мире. Они привлекли к разработке закона «О Национальной безопасности» 1947 г. не только военных и юристов, но и специалистов из иных сфер, в том числе и из области управления. (Президент - Совет Национальной Безопасности - (Министерство Внутренней Безопасности, Министерство Юстиции, Министерство Обороны, Министерство Финансов). Модель универсальна и взята на вооружение с учетом национальных особенностей всеми ведущими странами, в точности Россией.

\section{Библиографический список:}

1. Быков А.В. Система обеспечения внутренней безопасности государства. - М., 2007.

2. Губанов А.В. Полиция Запада. - М.,1993.

3. Крылов Б.С. Полиция США. - М., 1972.

4. Марченко М.Н., Байтин М.И., Керимов Д.А., Крылов Б.С., Мамут Л.С. Общая теория государства и права. Академический курс. 3-е изд. - М., 2007. Т. 1.

5. Попов И.М., Быков А.В., Губанов А.В., Капкин А.В. Внутренние войска (структуры им подобные) в системе обеспечения внутренней безопасности зарубежных государств (1945-1997 гг.). — М., 1998.

6. Хропанюк В.Н. Теория государства и права. - М.,1993.

7. Шалягин Д.Д. Полиция США. - М., 2001.

\section{References (transliteration):}

1. Bykov A.V. Sistema obespecheniya vnutrenney bezopasnosti gosudarstva. - M., 2007.

2. Gubanov A.V. Politsiya Zapada. - M., 1993.

3. Krylov B.S. Politsiya SShA. - M., 1972.

4. Marchenko M.N., Baytin M.I., Kerimov D.A., Krylov B.S., Mamut L.S. Obshchaya teoriya gosudarstva i prava. Akademicheskiy kurs.3-e izdanie. - M., 2007. T. 1.

5. Popov I.M., Bykov A.V., Gubanov A.V., Kapkin A.V. Vnutrennie voyska (struktury im podobnye) v sisteme obespecheniya vnutrenney bezopasnosti zarubezhnykh gosudarstv (1945-1997 gg.). — M., 1998.

6. Khropanyuk V.N. Teoriya gosudarstva i prava. — M., 1993.

7. Shalyagin D.D. Politsiya SShA. - M., 2001.

\footnotetext{
9 См.: Попов И.М., Быков А.В., Губанов А.В., Капкин А.В. Внутренние войска (структуры им подобные) в системе обеспечения внутренней безопасности зарубежных государств (1945-1997 гг.). - М.,1998. - С. 60.

${ }^{10}$ См.: Конституция США. - М., 1993. - С. 17.
} 